\title{
Reduced bioavailability of cyclosporine $A$ in rats by mung bean seed coat extract
}

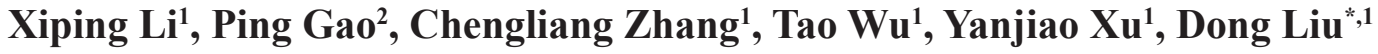 \\ ${ }^{1}$ Department of Pharmacy, Tongji Hospital, Tongji Medical College, Huazhong University of Science and Technology, Wuhan, \\ Hubei, China, ${ }^{2}$ Department of Pharmacy, Wuhan Children's Hospital, Wuhan, Hubei, China
}

\begin{abstract}
Mung bean seed coat (MBSC) is a healthcare product in Asian countries. The aim of this study was to investigate the effect of an MBSC ethanol extract on the bioavailability of cyclosporine A (CsA) in rats. Rats were orally dosed with CsA alone or in combination with MBSC ethanol extracts $(500 \mathrm{mg} / \mathrm{kg}$, p.o.). The blood levels of CsA were assayed by liquid chromatography with an electrospray ionization source and tandem mass spectrometry (LC-MS/MS). The everted rat intestinal sac technique was used to determine the influence of MBSC on the absorption of CsA. The results reveal that combined CsA intake with MBSC decreased the $\mathrm{C}_{\max }, \mathrm{AUC}_{0-\mathrm{t}}, \mathrm{t}_{1 / 2 \mathrm{z}}$ and $\mathrm{MRT}_{0-\mathrm{t}}$ values of CsA by $24.96 \%, 47.28 \%, 34.73 \%$ and $23.58 \%$, respectively $(P<0.05)$, and significantly raised the $\mathrm{CL} / \mathrm{F}$ by $51.97 \%(P<0.01)$. The in vitro results demonstrated that significantly less CsA was absorbed $(P<0.05)$. The overall results indicate that after being concomitantly ingested, MBSC reduced the bioavailability of CsA, at least partially, in the absorption phase.
\end{abstract}

Uniterms: Mung bean/seed coat/health care use. Mung bean/seed coat/ethanolic extract/properties. Cyclosporine A/bioavailability.

O tegumento da semente de feijão-mungo (MBSC) é um produto para tratamento de saúde em países asiáticos. O objetivo deste estudo foi investigar o efeito de extrato etanólico de MBSC na biodisponibilidade da ciclosporina A (CVsA) em ratos. Administrou-se aos ratos CsA sozinha ou em associação com extrato etanólico de MBSC (500 mg/kg, p.o.), por via oral. Os níveis sanguíneos de CSA foram determinados por cromatografia a líquido com ionização por electrospray, associada à espectrometria de massas (LC-MS/MS). Utilizou-se a técnica de inversão do saco intestinal de rato para determinar a influência do MBSC na absorção de CsA. Os resultados revelaram que a ingestão combinada de CsA e MBSC diminuiu os valores de $\mathrm{C}_{\max }, \mathrm{AUC}_{0-\mathrm{t}}, \mathrm{t}_{1 / 2 \mathrm{z}}$ e $\mathrm{MRT}_{0-\mathrm{t}}$ de CsA em 24\%, 47,28\%, 34,73\% e 23,58\%, respectivamente ( $\mathrm{P}<0.05)$, e aumentou, significativamente, $\mathrm{CL} / \mathrm{F}$ em $51,79 \%(\mathrm{P}<0.05)$. Os resultados in vitro demostraram que, significativamente, menos CsA foi absorvida $(\mathrm{P}<0.05)$. Os resultados totais indicaram que após ser concomitantemente ingerida, a MBSC reduziu, ao menos parcialmente, a biodisponibilidade de CsA, na fase de absorção.

Unitermos: Feijão-mungo/tegumento da semente/uso para a saúde. Feijão-mungo/tegumento da semente/ extrato etanólico/propriedades. Ciclosporina A/biodisponibilidade.

\section{INTRODUCTION}

In daily practice, drugs are often taken simultaneously with foods or nutriments. However, food-drug interactions (FDIs), with commonly overlooked hidden risks, unintentionally result in therapeutic failure or increased

"Correspondence: Dong Liu. Department of Pharmacy, Tongji Hospital, Tongji Medical College, Huazhong University of Science and Technology, 1095 Jiefang Avenue, 430030, Wuhan, China. E-mail: 1d2069@outlook.com toxicity of drugs, thus adversely affecting patient care, contributing to morbidity and prolonging treatment or hospitalization stay (Bushra, Slam, Khan, 2011). Therefore, identifying FDIs, understanding the relevant mechanisms, and evaluating and managing the risks are clinically significant before diagnosis and treatment protocol selection. Cyclosporine A (CsA), an important calcineurin inhibitor, ensures, at therapeutic concentrations, effective immunosuppression after transplants of a variety of solid organs. Sub-therapeutic CsA concentrations, 
which are prone to inducing acute cellular rejection, lead to hepatotoxicity, nephrotoxicity and neurotoxicity (Kuypers, 2008). Previously, Yang (2002) reported six patients who had received a renal transplantation and suffered from graft rejection after concomitantly drinking mung bean soup. The trough concentrations of CsA decreased from (390.00 \pm 112.21$) \mathrm{ng} / \mathrm{mL}$ before mung bean food intake to $(287.33 \pm 94.21) \mathrm{ng} / \mathrm{mL}(P<0.001)$ after.

Mung bean (Vigna radiatae L.) seed coat (MBSC) is a traditional Chinese medicine targeting several diseases, generally by reducing fever and removing toxic substances (Yao et al., 2008). Mung bean is a ubiquitous food because the embryo is abundant in nutrients such as starch, fiber and protein, while most bioactive phytochemicals are contained in the coats (Cao et al., 2011; Khan, Jacobsen, Eggum, 2006). Besides, the pharmacological effects of MBSC, such as antitumor (Soucek et al., 2006), antidiabetic (Peng et al., 2008), anti-inflammatory (Prabhakar et al., 1981), antimicrobial (Randhir, Lin, Shetty, 2004) and antioxidant (Soucek et al., 2006), have also been spotlighted. Hence, the present study mostly focused on the bioactivity of MBSC.

The purpose of this study was to verify the pharmacokinetic effects of mung bean seed coat (MBSC) on CsA. We designed a parallel experiment by pretreating rats with MBSC ethanol extract or vehicle solution for 7 consecutive days before the administration of CsA to investigate the resultant food-drug pharmacokinetic interaction. Furthermore, whether intestinal absorption was functionally modulated by MBSC was tested by everted gut sac studies.

\section{MATERIAL AND METHODS}

\section{Chemicals and reagents}

Dried MBSC was purchased from Hui-Rui Chinese Medicine Science Co., Ltd. (Bozhou, China). CsA (purity $>99 \%$ ) and tacrolimus (Internal standard, purity $>99 \%$ ) were obtained from the China Pharmacy Biological Products Examination Institute (Beijing, China). Cs A was donated by Zhongmei Huadong Pharmaceutical Co., Ltd. (Hangzhou, China). HPLC-grade methanol and acetonitrile were obtained from the Fisher Scientific Company (Emerson, USA). Other chemicals and reagents were all analytically pure (Jinfeng Chemical Factory, Tianjin, China).

\section{Experimental animals}

Male Sprague-Dawley rats, aged 8-9 weeks old, were purchased from the Experimental Animal Center of Tongji Medical College (Huazhong University of Science and Technology, China). The experimental rats were maintained at the Experimental Animal Center of Tongji Medical College under specific pathogen-free conditions. The rats were housed in stainless steel cages and kept at a controlled temperature $\left(25 \pm 2{ }^{\circ} \mathrm{C}\right)$ and ambient humidity ( $50 \%$ to $75 \%)$. Light was maintained following a $12 \mathrm{~h}$ dark-light cycle. All of the rats were continuously provided with a chow diet and tap water throughout the experiment. The experiments were carried out according to the National Institutes of Health Guide for the Care and Use of Laboratory Animals approved by the Animal Ethics Committee of Tongji Medical College, Huazhong University of Science and Technology.

\section{Preparation of the aqueous extract of MBSC}

MBSC (500 g) was pre-immersed in 50\% ethanol aqueous solution (solid: liquid, 1:10) and then refluxed at $80^{\circ} \mathrm{C}$ for $150 \mathrm{~min}$ and extracted three times. The combined extracts were filtered through gauze, to which was then added appropriate amounts of diatomaceous earth. This was stirred at ambient temperature for 2-3 $\mathrm{min}$, and then allowed to stand for $5 \mathrm{~min}$. After the removal of macromolecular compounds by adsorption, the solution was distilled under reduced pressure, and the combined dry residue was extracted with petroleum ether $(500 \mathrm{~mL})$ to remove lipidsoluble constituents. The aqueous phase was then collected, freeze-dried as the aqueous extract of MBSC and stored.

\section{Overall pharmacokinetics study}

Twelve rats (8-9 weeks old) were randomly divided into two groups, which were administered cyclosporine A (CsA) alone or in combination with MBSC extract respectively. Once daily for six consecutive days, the rats in the combined administration group were orally given $500 \mathrm{mg} / \mathrm{kg}$ MBSC extract (dissolved in 0.5\% CMC-Na), and those in the CsA group were orally administered with equal volumes of $0.5 \% \mathrm{CMC}-\mathrm{Na}$ solution. All rats had free access to food and water. On the seventh day, the rats were treated with vehicle or MBSC extract. The rats were fasted for no less than $12 \mathrm{~h}$ before intragastric administration, but retained free access to water. Meanwhile, the two groups were orally given $10 \mathrm{mg} / \mathrm{kg} \mathrm{CsA} \mathrm{(dissolved} \mathrm{in} \mathrm{olive} \mathrm{oil)}$ after 30 min of the above administration procedure. Blood $(0.3 \mathrm{~mL})$ was collected from the carotid artery at $0,0.83$, $1.5,3,5,6,8,12,24$ and $36 \mathrm{~h}$ after administration. Whole blood was stored at $-80^{\circ} \mathrm{C}$. After the experiment, the rats were sacrificed by cervical dislocation under anesthesia. 


\section{Everted intestinal sac study}

Twelve rats (8-9 weeks old) were randomly divided into a control group and an MBSC extract pretreatment group, in which the rats were orally administered with $0.5 \%$ CMC-Na solution and MBSC extract solution (dissolved in $0.5 \%$ CMC-Na) respectively once a day for six continuous days. On the seventh day, the rats were fasted for no less than $12 \mathrm{~h}$ before experiment with free water access. Thirty minutes after the corresponding pretreatment, the rats were fixed after ether anesthesia. Everted sacs were prepared by slightly modifying a procedure described previously (Sakamoto et al., 2006). The abdomens were incised open along the abdominal midline to carefully peel the intestinal canal off the mesentery. Then, $10 \mathrm{~cm}$ of the duodenum, jejunum, ileum and colon were disconnected, put into $37^{\circ} \mathrm{C}$ K-R buffer $(133 \mathrm{mM} \mathrm{NaCl}, 4.75 \mathrm{mM} \mathrm{KCl}, 3.33 \mathrm{mM}$ $\mathrm{CaCl}_{2}, 2.67 \mathrm{mM} \mathrm{NaH}_{2} \mathrm{PO}_{4}, 0.02 \mathrm{mM} \mathrm{MgCl}, 16.31 \mathrm{mM}$ $\mathrm{NaHCO}_{3}$, and $8.75 \mathrm{mM} \mathrm{C}_{6} \mathrm{H}_{12} \mathrm{O}_{6}, \mathrm{pH}$ 7.0-7.2) and washed until the exhaustion of intestinal contents, after which the mesentery and fat on the surface of intestinal segments were cautiously removed. The rats were sacrificed by cervical dislocation under anesthesia. After being ligated onto a self-prepared plastic sleeve with one end, the intestinal canal was carefully everted and rinsed with $\mathrm{K}-\mathrm{R}$ buffer, and then the other end was also ligated into a capsular shape. Blank K-R buffer $(1 \mathrm{~mL})$ was added to the intestinal sac, which was then put into a water bath already containing K-R buffer, magnetically stirred at $37{ }^{\circ} \mathrm{C}$ under a $95 \% \mathrm{O}_{2} / 5 \% \mathrm{CO}_{2}$ atmosphere. After $5 \mathrm{~min}$ of equilibrium, the original K-R buffer was removed from the water bath, into which was then added $250 \mathrm{~mL}$ of K-R liquid containing $5 \mu \mathrm{g} / \mathrm{mL}$ CsA. The solution $(200 \mu \mathrm{L})$ in the intestinal sac was sampled after $15,30,45,60,75$ and 90 min of incubation, and same volume of blank K-R buffer was added simultaneously. The absorptive solution was stored at $-80^{\circ} \mathrm{C}$ until analysis.

\section{Lactate dehydrogenase (LDH) release of everted gut sacs}

LDH is an intracellular enzyme, detected following damage to cell membranes, and has been used as a biochemical marker of intestinal wall damage (Brown et al., 2002; Swenson, Milisen, Curatolo, 1994). The feature was determined by means of LDH release tests, as previously reported (Rong et al., 2013).

\section{Analytical methods}

All analyses were conducted on a Shimadzu LC system equipped with two LC-20AD pumps, an SIL20ACHT autosampler, an SCL-10Avp control system, a DGU-20A3 on-line degasser and a CTO-20AC column oven (Chiyoda-Ku, Japan). Separation was performed on a Dimonsil $\mathrm{C}_{18}$ column $(150 \mathrm{~mm} \times 2.1 \mathrm{~mm}$ i.d., $5 \mathrm{~mm}$, Dikma, China) equipped with a Phenomenex guard column $(5.0 \mathrm{~mm} \times 2.0 \mathrm{~mm}$ i.d., Phonomenon, Guangzhou, China). The mobile phase consisted of methanol and $0.1 \%$ formic acid $(10: 90, \mathrm{v} / \mathrm{v})$. The temperature was maintained at $65{ }^{\circ} \mathrm{C}$ for the column and $15{ }^{\circ} \mathrm{C}$ for the autosampler. The flow rate was $0.3 \mathrm{~mL} / \mathrm{min}$. Mass spectrometric analyses were conducted on an API 3,200 LC-MS-MS system (Applied Biosystems, Foster City, USA) equipped with an electrospray ionization source (ESI) in triplequadrupole mode. The curtain gas and collision activated dissociation were 20 and 5 psi, respectively. The other working parameters were set as follows: spray voltage, 5,000 V; source temperature, $450{ }^{\circ} \mathrm{C}$; GAS 1, $60 \mathrm{psi}$ and GAS2, 45 psi. The declustering potential, entrance potential, collision energy and collision cell exit potential were optimized, respectively, as 77, 14, 20 and $22 \mathrm{~V}$ for $\mathrm{CsA}$; these values were 112, 34 and 70 and $8.0 \mathrm{~V}$ for sirolimus (IS). LC-ESI-MS-MS was performed in positive ionization mode with multiple reaction monitoring (MRM) of the transitions $\mathrm{m} / \mathrm{z}\left([\mathrm{M}+\mathrm{Na}]^{+}\right) 1225.8 \rightarrow \mathrm{m} / \mathrm{z} 1225.8$ for $\mathrm{CsA}$ and $\left(\left[\mathrm{M}+\mathrm{NH}_{4}\right]^{+}\right) \mathrm{m} / \mathrm{z} \quad 821.9 \rightarrow \mathrm{m} / \mathrm{z} 409.4$ for tacrolimus. Data acquisition and analysis were controlled using Analyst 1.5 software (Applied Biosystems).

\section{Sample preparation}

In this study, all samples were detected by liquid chromatography-electrospray ionization tandem mass spectrometry (LC-ESI-MS/MS). Rat whole blood $(200 \mu \mathrm{L})$ or the absorptive solution from the gut sac was placed in a $10 \mathrm{~mL}$ glass centrifuge tube, to which was then added $50 \mu \mathrm{L}$ of $5 \mathrm{M} \mathrm{NH}_{4} \mathrm{AC}$ to break the cells. The resultant solution was mixed for $1 \mathrm{~min}$ and allowed to stand for $10 \mathrm{~min}$, to which was then added $20 \mu \mathrm{L}$ of tacrolimus solution $(1.012 \mu \mathrm{g} / \mathrm{mL})$. This was the mixed, extracted with $3 \mathrm{~mL}$ of ether for $5 \mathrm{~min}$, and centrifuged at 3,500 rpm for $5 \mathrm{~min}$. The upper organic layer was collected and dried under a nitrogen stream at $40{ }^{\circ} \mathrm{C}$. The dried residue was redissolved in $100 \mu \mathrm{L}$ of the mobile phase, transferred to an EP tube, and centrifuged at 12,000 rpm for $5 \mathrm{~min}$, from which $10 \mu \mathrm{L}$ of the supernatant was collected for analysis.

\section{Data transformation}

The plasma concentration-time data were analyzed using the non-compartmental model in DAS2.0 to obtain 
the main pharmacokinetic parameters (Li et al., 2013; Zhang et al., 2012). Peak concentration $\left(\mathrm{C}_{\max }\right)$ and timeto-peak $\left(\mathrm{t}_{\max }\right)$ were measured, area under the plasma concentration-time curve (AUC) was calculated by the trapezoidal rule, and the half-life of elimination $\left(\mathrm{t}_{1 / 2}\right)$ was calculated by $0.693 / \mathrm{ke}$ (ke refers to the terminal elimination rate constant derived from the slope of terminal straight line of logarithmic plasma concentration-time curve). The apparent clearance rate of oral administration $(\mathrm{CL} / \mathrm{F})$ was calculated by dose $/ \mathrm{AUC}_{0-\mathrm{t}}$. All the other parameters were calculated based on the non-compartmental model, and the mean residence time (MRT) of drug molecules was calculated as $1.44 \mathrm{t}_{1 / 2}$.

The rate of drug transport was usually expressed as the apparent permeability coefficient $\left(P_{\text {app }}\right)$. It was calculated from the following equation:

$$
\text { Papp }=(d Q / d t) /\left(C_{0} \times A\right)
$$

where $d Q / d t$ is the steady-state appearance rate on the acceptor solution, $\mathrm{A}$ is the surface area of the intestinal sac and $\mathrm{C}_{0}$ is the initial concentration inside the sac.

\section{STATISTICAL ANALYSIS}

The experimental data were expressed as mean \pm SD or mean, and were analyzed by SPSS 16.0 (Li, et al., 2013; Zhang et al., 2012). The main parameters of each group were subjected to one-way analysis variance (ANOVA) and Student's t-test, with $P<0.05$ being statistically significantly different.

\section{RESULTS AND DISCUSSION}

\section{Method validation}

Briefly, the seven-point calibration curve for $\mathrm{CsA}(0$, $50,100,200,400,600$ and $1200 \mathrm{ng} / \mathrm{mL}$ ) was constructed by plotting the peak area ratio of CsA-IS against the real concentration of the calibration standards in rat plasma and K-R buffer. Inter-day and intra-day repeatability were assessed with QC samples (50, 200 and $1000 \mathrm{ng} / \mathrm{mL}$ of CsA in rat whole blood or absorptive solution of gut sac). The accuracy and precision were defined by the percentage of relative standard deviation (RSD) of five standards at five different concentrations analyzed on the same day. Stability was expressed by the relative error between the initial and tested concentration of QC samples under different sample preparatory conditions, such as short-term, long-term, freeze-thaw cycle and postpreparation stability. The results indicate that the lower limit of quantification was $50 \mathrm{ng} / \mathrm{mL}$ with a precision (RSD) less than $9.01 \%$ and a accuracy ranging from $94.5 \%$ to $107.76 \%$. The recovery of CsA was no less than $87.3 \%$ with a coefficient of variation less than $3.2 \%$. Short-term, long-term and three freeze-thaw stability studies indicated that analytes were stable under the above conditions. Ion suppression and enhancement from plasma and K-R buffer matrix were negligible under the present conditions.

\section{LDH release in the everted gut sac model}

The results reveal that there were no significant differences in LDH activity at 30, 60, 90 and $120 \mathrm{~min}$, while a significant difference was found at $180 \mathrm{~min}$, suggesting that the everted gut sacs began to lose viability after $120 \mathrm{~min}$. It was concluded that the everted gut sacs maintained their viability during the experimental period (90 min) and consequently this model was suitable for testing drug transport.

\section{Effects of MBSC on the pharmacokinetics of CsA in rats}

The whole blood concentration-time curves of CsA after oral dosing with CsA alone and in combination with MBSC are illustrated in Figure 1. The pharmacokinetic parameters of CsA are shown in Table I. Pretreating the rats with MBSC significantly reduced the $\mathrm{C}_{\max }, \mathrm{AUC}_{0-\mathrm{t}}, \mathrm{t}_{1 / 2 \mathrm{z}}$ and MRT of CsA by $24.96 \%(P<0.05), 47.28 \%(P<0.01)$, $34.73 \%(P<0.05)$ and $23.58 \%(P<0.01)$, respectively, and significantly elevated $\mathrm{CL} / \mathrm{F}$ by $51.97 \%(P<0.01)$.

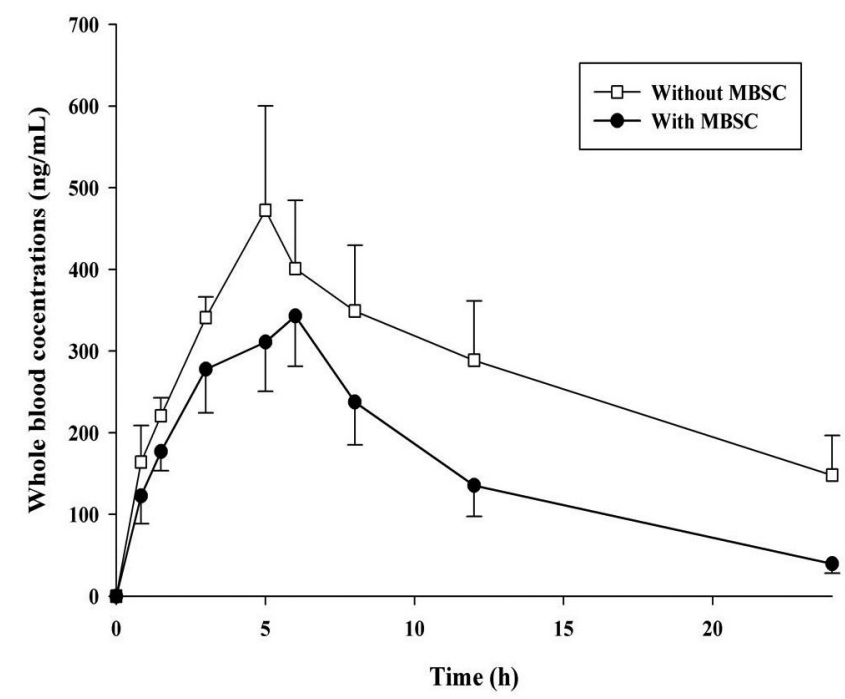

FIGURE 1 - Mean blood concentration-time curve of CsA after oral administration with or without MBSC extract $(500 \mathrm{mg} / \mathrm{kg}$, i.g.). Each point represents the mean $\pm \mathrm{SD}$. $(\mathrm{n}=6)$. 
TABLE I - Effect of treatment with herbal extract on the pharmacokinetic parameters of CsA

\begin{tabular}{lcc}
\hline Parameters & CsA alone & CsA+ MBSCs \\
\hline $\mathrm{AUC}_{0-\mathrm{t}}(\mathrm{ng} \cdot \mathrm{h} / \mathrm{mL})$ & $7846.32 \pm 988.49$ & $4137.10 \pm 281.34^{* *}$ \\
$\mathrm{t}_{1 / 2 \mathrm{z}}(\mathrm{h})$ & $13.36 \pm 2.41$ & $8.72 \pm 2.57^{*}$ \\
$\mathrm{C}_{\max }(\mathrm{ng} / \mathrm{mL})$ & $493.87 \pm 102.69$ & $370.60 \pm 31.48^{*}$ \\
$\mathrm{~T}_{\max }(\mathrm{h})$ & $5.20 \pm 1.17$ & $5.40 \pm 0.49$ \\
$\mathrm{CL} / \mathrm{F}(\mathrm{L} / \mathrm{h})$ & $1.10 \pm 0.18$ & $2.29 \pm 0.21^{* *}$ \\
$\mathrm{MRT}(\mathrm{h})$ & $13.19 \pm 1.04$ & $10.08 \pm 0.60^{* *}$ \\
\hline
\end{tabular}

Each point represents the mean \pm S.D. $(\mathrm{n}=6) .{ }^{*} p<0.05, * * p<0.01$, significantly different compared with CsA alone

\section{Effects of MBSC on CsA absorption in intestinal} gut sacs

Figure 2 shows the effects of MBSC treatment on the absorption of CsA in the duodenum, jejunum, ileum and colon. Table II shows the $P_{\text {app }}$ of CsA in each intestinal
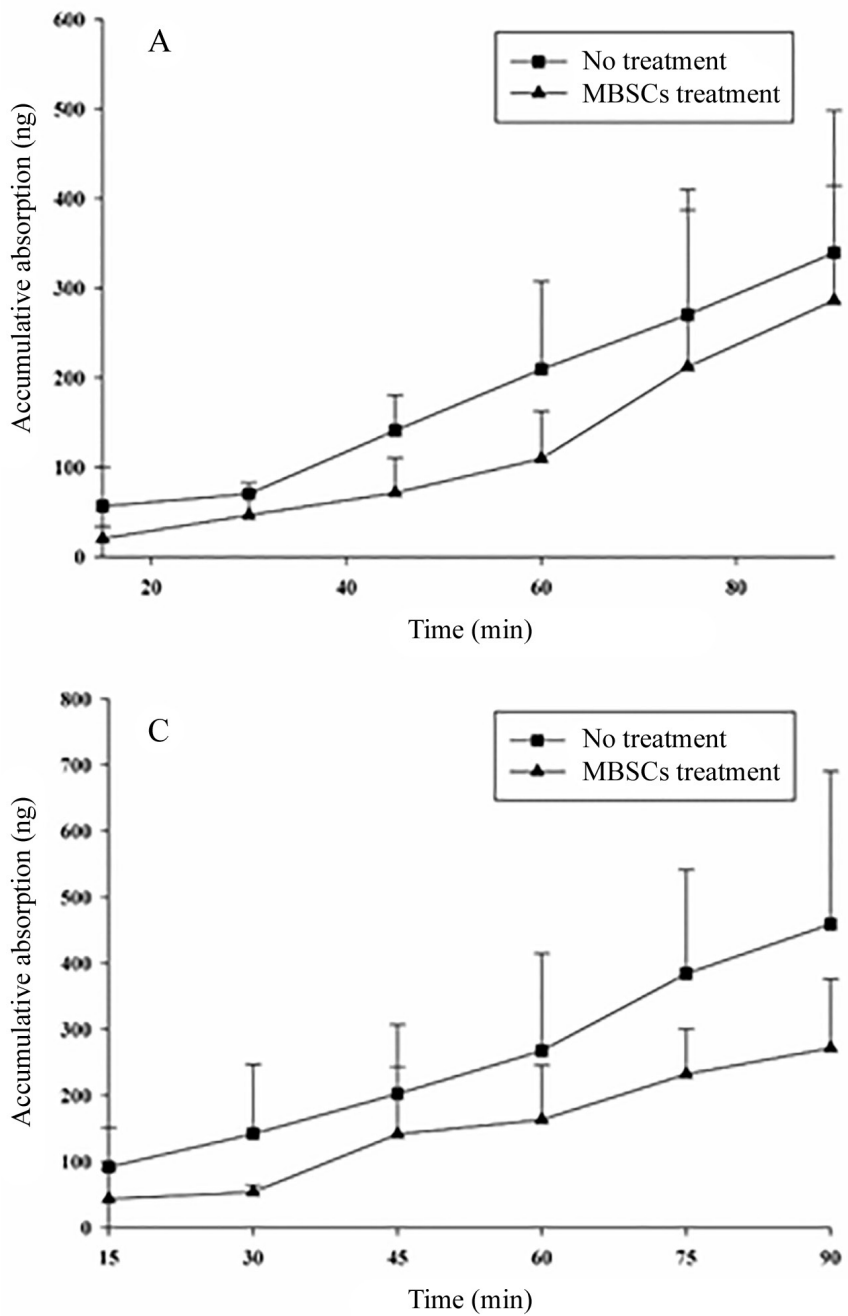

segment in the everted gut sac study. The results demonstrate that the rank order of $P_{\text {app }}$ of CsA in each intestinal segment was as follows: ileum $>$ duodenum $\approx$ jejunum $>$ colon. The ileum showed the greatest permeability, which is consistent with previously published data (Drewe, Beglinger, Kssel, 1992; Huang et al., 2010). Pretreatment with multiple
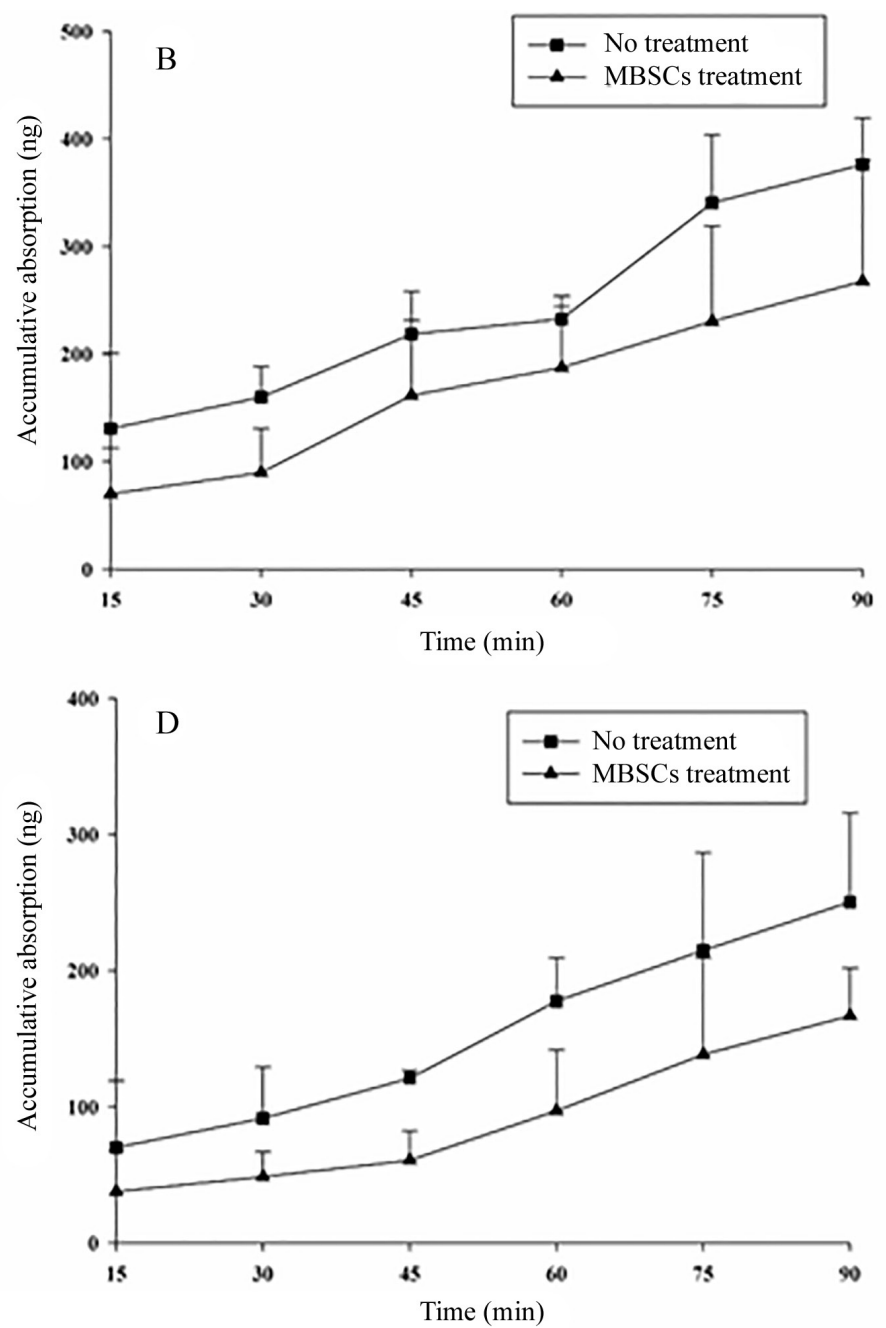

FIGURE 2 - Average transport of CsA (ng) from the mucosal to serosal surface across duodenum, jejunum, ileum and colon with or without MBSC extract pretreatment $(500 \mathrm{mg} / \mathrm{kg}$, i.g. $)$. Each point represents the mean \pm SD. $(\mathrm{n}=3)$. 
TABLE II - Apparent permeability of CsA in each intestinal segment in everted gut sac study

\begin{tabular}{lcc}
\hline & CsA alone & CsA+MBSCs \\
& $\left(P_{\text {app }}, 10^{-4} \mathrm{~cm} / \mathrm{s}\right)$ & $\left(P_{a p p}, 10^{-4} \mathrm{~cm} / \mathrm{s}\right)$ \\
\hline Duodenum & $10.83 \pm 1.14$ & $9.42 \pm 2.17$ \\
Jejunum & $9.01 \pm 1.03$ & $7.26 \pm 3.04^{*}$ \\
Ileum & $13.29 \pm 5.21$ & $8.57 \pm 2.75^{*}$ \\
Colon & $6.71 \pm 1.55$ & $4.87 \pm 0.97^{*}$ \\
\hline
\end{tabular}

Each point represents the mean $\pm \mathrm{SD}(\mathrm{n}=4) ; * P<0.05$, significantly different compared with CsA alone

doses of MBSC decreased the $P_{\text {app }}$ of CsA in most intestinal segments, except for the duodenum. Altogether, the results reveal that pretreatment with $500 \mathrm{mg} / \mathrm{kg}$ MBSC significantly decreased the $P_{\text {app }}$ of CsA in the jejunum, ileum and colon $(P<0.05)$.

In this study, combined intake of CsA with MBSC markedly decreased the $\mathrm{AUC}_{0-\mathrm{t}}(P<0.01), \mathrm{C}_{\max }(P<0.05)$, $\mathrm{t}_{1 / 2 z}(P<0.05)$ and MRT $(P<0.01)$ of CsA, and remarkably increased the $\mathrm{CL} / \mathrm{F}(P<0.01)$, demonstrating significantly reduced bioavailability of CsA. The semi-log profiles (data not shown) indicate that MBSC seemed to inhibit the intestinal absorption and enhanced the intestinal/ liver elimination of CsA. It is acknowledged that combined intake of CsA with foods and beverages can affect the rate and extent of drug absorption (Chiang et al., 2006), probably by impacting intestinal physiological factors and transport (Boullata, Hudson, 2012). Our everted gut sac study indicates that MBSC significantly decreased the accumulative absorption of CsA in each intestinal segment, suggesting that reduced CsA bioavailability occurs, at least partially, at the absorption site. Given that accelerated transit of a drug through the gastrointestinal tract reduces its absorption, MBSC might shorten drug transit time like ginger does (Platel, Srinivasan, 2001). In the meantime, CsA is metabolized in the intestine/liver by CYP3A4, and the parent drug is subjected to efflux by P-gp in the intestinal apical membrane (Pal, Mitra, 2006). Dürr reported that St John's wort lowers the blood concentration of CsA by inducing CYP3A4 and intestinal P-gp in humans (Dürr et al., 2000). In addition, Yang reported that the ingestion of ginkgo and onion decreases the bioavailability of CsA via inducing CYP3A in rats (Yang et al., 2006). Moreover, Chiang also found that ginger reduces the blood concentration of CsA by the induction of CYP3A4 (Chiang et al., 2006). However, whether MBSC can accelerate the metabolism of CsA by inducing intestinal or liver CYP3A in rats, or increase the efflux of CsA by inducing intestinal P-gp expression or activity remain unknown. The underlying mechanisms should be further clarified in future.

\section{CONCLUSIONS}

The present study was conducted to verify the interaction between MBSC and CsA. The results of this study demonstrate that combined treatment with CsA and MBSC could significantly reduce the oral bioavailability of CsA, at least partially by inhibiting absorption, suggesting that combined use of MBSC with CsA should be closely monitored for potential food-drug interactions.

\section{ACKNOWLEDGMENTS}

This research was supported by the Fundamental Research Funds for the Central Universities (HUST: 2012QN182).

\section{REFERENCES}

BUSHRA, R.; SLAM, N.; KHAN, A.Y. Food-drug interactions. Oman. Med. J., v.26, n.2, p.77-83, 2011.

BOULLATA, J.I.; HUDSON, L.M. Drug-nutrient interactions: a broad view with implications for practice. J. Acad. Nutr. Diet, v.112, n.4, p.506-517, 2012.

BROWN, J.R.; COLLETT, J.H.; ATTWOOD, D.; LEY, R.W.; SIMS, E.E. Influence of monocaprin on the permeability of a diacidic drug BTA-243 across Caco-2 cell monolayers and everted gut sacs. Int. J. Pharm., v.245, n.1, p.133-142, 2002.

CAO, D.; LI, H.; YI, J.; ZHANG, J.; CHE, H.; CAO, J., YANG, L.; ZHU, C.; JIANG, W. Antioxidant properties of the mung bean flavonoids on alleviating heat stress. PLoS One, v.6, n.6, p.1, 2011.

CHIANG, H.M.; CHAO, P.D.; HSIU, S.L.; WEN, K.C.; TSAI, S.Y.; HOU, Y.C. Ginger significantly decreased the oral bioavailability of cyclosporine in rats. Am. J. Chin. Med., v.34, n.5, p.845-855, 2006. 
DÜRR, D.; STIEGER, B.; KULLAK-UBLICK, G.A.; RENTSCH, K.M.; STEINERT, H.C.; MEIER, P.J.; FATTINGER, K. St John's Wort induces intestinal P-glycoprotein/MDR1 and intestinaland hepatic CYP3A4. Clin. Pharmacol. Ther, v.68, n.6, p.598-604, 2000.

DREWE, J.; BEGLINGER, C.; KSSEL, T. The absorption site of cyclosporin in the human gastrointestinal tract. Br. J. Clin. Pharmacol., v.33, n.1, p.39-43, 1992.

HUANG, Q.; XU, J.; BEI, Y.Y.; LIU, Y.; TANG, J.Z.; ZHANG, X.N. Studies on mechanism to promote intestinal absorption of cyclosporine A \& formulation factors. Anti-Infect. Pharm., v.7, n.4, p.246-250, 2010.

KUYPERS, D.R. Influence of interactions between immunosuppressive drugs on therapeutic drug monitoring. Ann. Transplant., v.13, n.3, p.11-18, 2008.

KHAN, M.A.; JACOBSEN, I.; EGGUM, B.O. Nutritive value of some improved varieties of legumes. J. Sci. Food Agric., v.30, n.4, p.395-400, 2006.

LI, X.P.; ZHANG, C.L.; GAO, P.; GAO, J.; LIU, D. Effects of andrographolide on the pharmacokinetics of aminophylline and doxofylline in rats. Drug Res. (Stuttg), v.63, n.5, p.258262, 2013.

PENG, X.; ZHENG, Z.; CHENG, K.W.; SHAN, F.; REN, G.X.; WANG, M. Inhibitory effect of mung bean extract and its costituents vitexin and isovitexin on the formation of advanced glycation endproducts. Food Chem., v.106, n.2, p.475-481, 2008.

PRABHAKAR, M.C.; BANO, H.; HUMAR, I.; PRABHAKAR, M.C.; BANO, H.; KUMAR, I.; SHAMSI, M.A.; KHAN, S.Y. Pharmacological investigations on vitexin. Planta Med., v.43, n.4, p.396-403, 1981.

PLATEL, K.; SRINIVASAN, K. Studies on the influence of dietary spices on food transit time in experimental rats. Nutr. Res., v.21, n.9, p.1309-1314, 2001.

PAL, D.; MITRA, A.K. MDR- and CYP3A4-mediated drugherbal interactions. Life Sci., v.78, n.18, p.2131-2145, 2006.
RANDHIR, R.; LIN, Y.T., SHETTY, K.F. Stimulation of phenolics, antioxidant and antimicrobial activities in dark germinated mung bean sprouts in response to peptide and phytochemical elicitors. Process Biochem., v.39, n.5, p.637646, 2004.

RONG, Z.H.; XU, Y.J.; ZHANG, C.L.; XIANG, D.C.; LI, X.P.; LIU, D. Evaluation of intestinal absorption of amtolmetin guacyl in rats: Breast cancer resistant protein as a primary barrier of oral bioavailability. Life Sci., v.92, n.3, p. 245$251,2013$.

SAKAMOTO, S.; SUZUKI, H.; KUSUHARA, H.; SUGIYAMA, Y. Efflux mechanism of taurocholate across the rat intestinal basolateral membrane. Mol. Pharm., v.3, n.3, p.275-281, 2006.

SOUCEK, J.; SKVOR, J.; POUCKOVA, P.; MATOUSEK, J.; SLAViK, T.; MATOUSEK, J. Mung bean sprout (phaseolus aureus) nuclease and its biological and antitumor effects. Neoplasma, v.53, n.5, p.402-409, 2006.

SWENSON, E.S.; MILISEN, W.B.; CURATOLO, W. Intestinal permeability enhancement: efficacy, acute local toxicity, and reversibility. Pharm. Res., v.11, n.8, p.1132-1142, 1994.

YANG, C.Y.; CHAO, P.D.; HOU, Y.C.; TSAI, S.Y.; WEN, K.C.; HSIU, S.L. Marked decrease of cyclosporin bioavailability caused by coadministration of ginkgo and onion in rats. Food Chem. Toxicol., v.44, n.9, p.1572-1578, 2006.

YANG, Z.H.; ZHANG, Z.; LIU, N.B. JIONG, Y.J. Influence of mung bean food on blood CsA concentration in renal transplantation patients. China Pharm. J., v.37, n.3, p.229230, 2002.

YAO, Y.; CHEN, F.; WANG, M.; WANG, J.; REN, G. Antidiabetic activity of mung bean extracts in diabetic KK-Ay mice. J. Agric. Food Chem., v.56, n.19, p.8869$8873,2008$.

ZHANG, C.L.; GAO, P.; YIN, W.F.; XU, Y.J.; XIANG, D.C.; LIU, D. Dexamethasone regulates differential expression of carboxylesterase 1 and carboxylesterase 2 through activation of nuclear receptors. J. Huazhong Univ. Sci. Technolog. Med. Sci., v.32, n.6, p.798-805, 2012.

Received for publication on $10^{\text {th }}$ September 2013 Accepted for publication on $16^{\text {th }}$ January 2014 
